\title{
MEMBANGUN INTENSI BERWIRAUSAHA MELALUI PENDIDIKAN KEWIRAUSAHAAN, EFIKASI DIRI DAN KEBUTUHAN BERPRESTASI MAHASISWA FAKULTAS EKONOMI UNIVERSITAS WARMADEWA
}

\author{
Putu Ayu Dian Darmayanti ${ }^{1}$ \\ I Gst A. Kt Gd Suasana ${ }^{2}$ \\ ${ }^{1,2}$ Fakultas Ekonomi dan Bisnis Universitas Udayana, Bali, Indonesia \\ email: dian.darmayanti@ rocketmail.com
}

\begin{abstract}
ABSTRAK
Penelitian ini bertujuan untuk menjelaskan pengaruh pendidikan kewirausahaan, efikasi diri dan kebutuhan akan prestasi terhadap intensi berwirausaha mahasiswa S1 reguler Fakultas Ekonomi Universitas Warmadewa angkatan 2015. Penelitian ini dilakukan di Fakultas Ekonomi Universitas Warmadewa. Jumlah sampel yang digunakan 100 responden dengan menggunakan teknik dengan menggunakan teknik non probability sampling, khususnya purposive sampling. Hasil pengujian hipotesis menunjukkan pendidikan kewirausahaan, efikasi diri dan kebutuhan akan prestasi secara signifikan berpengaruh positif terhadap intensi berwirausaha. Berdasarkan hasil penelitian tersebut, calon wirausahawan ataupun mahasiswa ada baiknya memperhatikan pengaruh pendidikan kewirausahaan, efikasi diri dan kebutuhan akan prestasi sebagai bahan pertimbangan dalam mengaplikasikan intensi berwirausaha, karena ketiga variabel ini secara signifikan berpengaruh positif terhadap intensi berwirausaha
\end{abstract}

Kata kunci : pendidikan kewirausahaan, efikasi diri, kebutuhan akan prestasi, intensi berwirausaha

\begin{abstract}
This aims of this study for explain the influence of entrepreneurship education, self efficacy and the need for achievement of the entrepreneurship intentions of regular S1 students Faculty of Economics, University of Warmadewa force 2015. This research was conducted at the Faculty of Economics, University of Warmadewa. The number of samples used 100 respondents by using techniques using non probability sampling techniques, especially purposive sampling. The results of hypothesis testing showed that entrepreneurship education, self efficacy and the need for achievement significantly had a positive effect on the intention of entrepreneurship. Based on the results of this study, prospective entrepreneurs or students are good to pay attention to the influence of entrepreneurship education, self efficacy and the need for achievement as a consideration in applying the intensi entrepreneurship, because these three variables significantly positively affect the intention of entrepreneurship.
\end{abstract}

Keywords : entrepreneurship education, self efficacy, need for achievement, entrepreneurship intentions 
Putu Ayu Dian Darmayanti, Membangun Intensi Berwirausaha...

\section{PENDAHULUAN}

Indonesia adalah negara nomor empat dengan jumlah penduduk terbanyak di dunia, setelah China, India, dan Amerika Serikat. Menurut CIA (Central Intellegence Agency) World Factbook tahun 2015 jumlah penduduk di Indonesia mencapai 255.993.674 jiwa atau sekitar 3,5 persen dari keseluruhan jumlah penduduk dunia (http://ilmupengetahuanumum.com, diakses pada tanggal 20 Pebruari 2017). Melihat angka jumlah penduduk Indonesia yang semakin banyak, masalah perekonomian merupakan salah satu masalah yang perlu di perhatikan. Semakin banyak populasi penduduk dalam suatu negara, dapat menimbulkan dampak pada perekonomian negara tersebut. Dampak negatif yang dapat ditimbulkan akibat masalah perekonomian adalah banyaknya penduduk Indonesia yang tidak mendapatkan pekerjaan di usianya yang produktif (pengangguran).

Data statistik menunjukkan bahwa jumlah penduduk Indonesia tahun 2016 sebanyak 257.912.349 jiwa. Menurut data Badan Pusat Statistik, jumlah pengangguran lulusan perguruan tinggi tahun 2016 mencapai 13 persen (BPS Nasional , 2016). Menurut data Badan Pusat Statistik tahun 2016 jumlah pengangguran terbuka di provinsi Bali sebanyak 46.480 orang. Angka tersebut menandakan bahwa masih banyaknya jumlah pengangguran di Indonesia khususnya di Provinsi Bali yang sangat membutuhkan pekerjaan. Setiap warga Negara Indonesia sebaiknya memiliki sikap mental kewirausahaan agar mampu memecahkan persoalannya sendiri, dengan melihat dan memanfaatkan peluang 
untuk membesarkan produktivitas dan nilai tambahnya (Suparta dan Ramantha, 2010:2)

Lulusan terdidik diharapkan mulai memikirkan untuk berwirausaha, melihat keadaan lapangan pekerjaan di Indonesia yang semakin sempit. Berwirausaha memberikan banyak dampak positif bagi perekonomian negara. Menurut Baumol., et al (2007) bahwa kewirausahaan adalah kunci untuk sejumlah hasilhasil sosial yang diinginkan, termasuk pertumbuhan ekonomi, pengangguran yang lebih rendah, dan modernisasi teknologi. McCleeland (1961) menyebutkan bahwa suatu negara dapat maju minimal 2 persen dari total penduduk suatu negara berprofesi sebagai wirausaha. Menteri Koperasi dan UKM Anak Agung Gede Ngurah Puspayoga mengungkapkan, jumlah pengusaha di Indonesia meningkat dari yang sebelumnya hanya sebesar 1,67 persen menjadi 3,10 persen dalam acara GKN 2017 dan penyerahan penghargaan para pemenang Wirausaha Muda Mandiri 2016, di Graha Widya Wisuda Institut Pertanian Bogor (IPB), Sabtu 11 Maret 2017. Menkop Puspayoga menjelaskan, berdasarkan data BPS 2016 dengan jumlah penduduk 257 juta, jumlah wirausaha non pertanian yang menetap mencapai 7,8 juta orang atau 3,1 persen. Menkop Puspayoga mengakui, ratio wirausaha sebesar 3,1 persen itu masih lebih rendah dibandingkan dengan negara lain seperti Malaysia 5 persen, China 10 persen, Singapura 7 persen, Jepang 11 persen maupun AS yang 12 persen (www.depkop.go.id. diakses pada tanggal 07 Juni 2017).

Masalah pengangguran yang masih banyak di kalangan terdidik, mulai dipikirkan dengan serius oleh pemerintah. Pemerintah Indonesia mulai 
Putu Ayu Dian Darmayanti, Membangun Intensi Berwirausaha...

membentuk program di bidang kewirausahaan yaitu Gerakan Kewirausahaan Nasional yang diusung oleh Kementrian Koperasi dan UKM Negara Republik Indonesia sejak Tanggal 2 Februari 2011. Gerakan ini bertujuan untuk meningkatkan populasi wirausaha dan mengentaskan pengangguran di Indonesia (http://www.kopagi.com, diakses pada tanggal 20 Pebruari 2017). Pemerintah saat ini mulai memperkenalkan pengembangan dan pendidikan kewirausahaan di seluruh perguruan tinggi yang ada di Indonesia. Pihak universitas mulai menyadari bahwa mahasiswa seharusnya berpeluang besar untuk menjadi seorang wirausaha (entrepreneur) karena melihat angka pengangguran yang tinggi berasal dari gelar sarjana.

Universitas sudah menawarkan pelatihan atau mata kuliah kewirausahaan sebagai kurikulum pembelajaran mereka yang bertujuan untuk mempersiapkan mahasiswa menjadi seorang yang independen dan tidak bergantung secara finansial kepada orang lain (Basu \& Virick, 2007). Peningkatan terhadap aktivitas kewirausahaan dan pendidikan kewirausahaan ini seperti peningkatan inovasi dan kompetisi dalam berwirausaha akan membentuk pertumbuhan ekonomi dan menciptakan tenaga kerja (Leon et al., 2007).

Theory of Planned Behavior Ajzen, (Ajzen, 1991) menyatakan bahwa niat (intensi) seseorang untuk melakukan suatu perilaku, niat merupakan variabel antara yang menyebabkan terjadinya perilaku dari suatu sikap maupun variabel lainnya. Niat merupakan mediator pengaruh berbagai faktor-faktor motivasional yang berdampak pada suatu perilaku. Niat juga menunjukkan seberapa keras seseorang berani mencoba, niat menunjukkan seberapa besar upaya yang 
direncanakan seseorang untuk dilakukannya dan niat adalah paling dekat berhubungan dengan perilaku selanjutnya (Wijaya, 2008).

Kemiskinan dan rendahnya daya saing negara dapat diatasi dengan meningkatkan pendidikan maupun budaya berwirausaha sebagai upaya untuk memecahkan permasalahan tingginya tingkat pengangguran. Peningkatan pendidikan diharapkan dapat memberikan pengetahuan dan kemampuan masyarakat untuk dapat menguasai pengetahuan dan teknologi, sehingga mereka mampu bersaing dalam dunia kerja secara profesional. Upaya untuk meningkatkan budaya berwirausaha diharapkan dapat mendorong terciptanya wirausaha baru yang tidak saja mampu menciptakan usaha, tetapi sekaligus dapat menyerap tenaga kerja terdidik sehingga produk yang dihasilkan mampu bersaing di pasar (Kennedy \& Drennan, 2001). Program pendidikan kewirausahaan (Education Enterpreneurship Programme / EEP) ditujukan untuk mempengaruhi masa depan perilaku kewirausahaan individu dan meningkatkan kesuksesan bisnis. Program tersebut bertujuan untuk meningkatkan minat mahasiswa tentang karir kewirausahaan dan untuk meningkatkan kesadaran para pejabat publik tentang pentingnya kewirausahaan sebagai kontributor untuk pembangunan ekonomi (Fayole et al, 2006).

Pendidikan kewirausahaan dapat membentuk pola pikir, sikap, dan perilaku pada mahasiswa menjadi seorang wirausahawan (entrepreneur) sejati sehingga mengarahkan mereka untuk memilih berwirausaha sebagai pilihan karir. Pengaruh tersebut perlu dikaji lebih lanjut apakah dengan adanya mata kuliah kewirausahaan dapat melahirkan minat berwirausaha bagi mahasiswa. Perlu 
Putu Ayu Dian Darmayanti, Membangun Intensi Berwirausaha...

adanya penelitian untuk mengidentifikasi faktor yang mendorong minat berwirausaha mahasiswa mengingat pentingnya kewirausahaan bagi kesejahteraan ekonomi dan sosial.

Efikasi diri (self efficacy) merupakan salah satu model dari perilaku kewirausahanan yang perlu ditanamkan sejak dini. Perilaku kewirausahaan dipandang dari perspektif sosiologi menjelaskan hubungan antara manusia, pola hidup masyarakat, norma dan budaya membentuk kelompok yang terbentuk dari perilaku kewirausahaan. Menurut Hamilton \& Harper (1994), menjelaskan bahwa psikologi perspektif yang dibahas melalui perilaku kewirausahaan dipandang dari faktor psikologis adalah aspek pribadi dan motif kewirausahaan. Menurut Robert \& Shepherd (2008), orang yang percaya akan kemampuan dan keyakinan yang ia miliki, akan menunjukan pencapaian hasil yang baik. Pengertian ini menunjukan bahwa pengaruh efikasi diri mempengaruhi kesuksesan pencapaian seseorang dalam berwirausaha. Menurut Bandura (1997) mendefinisikan efikasi diri sebagai keyakinan seseorang terhadap kemampuannya dalam mengorganisasikan serangkaian tindakan yang dibutuhkan untuk mencapai tujuan yang dikehendaki. Jika seorang wirausaha memiliki rasa efikasi diri yang tinggi maka tujuan di dalam mengembangkan suatu usaha dapat segera tercapai. Jika seseorang memiliki efikasi diri yang tinggi maka seseorang tersebut akan memiliki inisiatif dan ketekunan untuk meningkatkan usaha dan kinerjanya. Begitu pula sebaliknya, jika seseorang memiliki efikasi diri yang rendah, maka seseorang tersebut akan mengurangi usaha dan kinerjanya. 
Kebutuhan akan prestasi merupakan sikap untuk menjadi pemenang atau meraih keberhasilan. Needs Theory (McCleeland, 1961) dijelaskan bahwa kebutuhan akan prestasi berpengaruh terhadap intensi. McClelland menyebutkan bahwa konsep kebutuhan akan prestasi yang dapat menyebabkan individu ingin berbuat lebih baik dan terus maju dengan mengambil tindakan berisiko setelah melakukan perhitungan akan dampak dari keputusan yang diambil (Suryana, 2007:52). McClelland juga menunjukkan bahwa jatuh bangunnya negara-negara berserta kebudayaannya berhubungan erat dengan perubahan pada kebutuhan untuk berprestasi (Sinulingga, 2012). Kebutuhan akan prestasi ini menimbulkan sikap untuk ingin diberi penghargaan dan mencapai semua tujuan yang telah di rencanakan. Sikap inilah yang seharusnya seorang wirausahawan miliki.

Menurut Indarti \& Rostiani (2008) latar belakang pendidikan seseorang terutama yang terkait dengan bidang usaha, manajemen dan ekonomi akan mempengaruhi keinginan dan minatnya untuk memulai usaha baru di masa mendatang. Selain itu menurut Suharti \& Sirine (2011), menyatakan bahwa salah satu faktor pendorong pertumbuhan kewirausahaan disuatu negara terletak pada peranan universitas melalui penyelenggaraan pendidikan kewirausahaan. Pihak universitas bertanggung jawab dalam mendidik dan memberikan kemampuan berwirausaha untuk memberikan motivasi kepada para lulusannya sehingga berwirausaha menjadi pilihan karir yang tepat. Pihak perguruan tinggi perlu menerapkan pola pembelajaran kewirausahaan yang kongkrit berdasar masukan empiris untuk membekali mahasiswa dengan pengetahuan yang bermakna agar dapat mendorong semangat mahasiswa untuk berwirausaha ( $\mathrm{Wu} \& \mathrm{Wu}, 2008)$. 
Putu Ayu Dian Darmayanti, Membangun Intensi Berwirausaha...

Penelitian dilakukan di Fakultas Ekonomi Universitas Warmadewa, lokasi tersebut merupakan salah satu fakultas yang berada di lingkungan universitas Warmadewa yang memberikan mata kuliah kewirausahaan di setiap jurusan. Visi dari Fakultas Ekonomi Universitas Warmadewa searah dengan tujuan dari penilitian ini yaitu menghasilkan lulusan ekonomi yang unggul, beretika, berorientasi lingkungan dan mandiri sehingga mampu menciptakan lapangan kerja sendiri dan memberikan mata kuliah yang dapat menciptakan jiwa berwirausaha di mata mahasiswa (FE Unwar, 2010). Penelitian ini difokuskan untuk mahasiswa S1 Reguler Fakultas Ekonomi. Alasan mahasiswa Fakultas Ekonomi Unwar menarik untuk diteliti karena Fakultas Ekonomi Unwar merupakan fakultas ekonomi universitas swasta yang memiliki jumlah mahasiswa $\mathrm{S} 1$ reguler terbanyak di Denpasar. Berikut adalah data jumlah mahasiswa ekonomi S1 reguler angkatan 2015 fakultas ekonomi universitas swasta di Denpasar : Fakultas Ekonomi Universitas Pendidikan Nasional memiliki 577 orang mahasiswa, Fakultas Ekonomi Universitas Hindu Indonesia memiliki 471 orang mahasiswa, Fakultas Ekonomi Universitas Mahasaraswati memiliki 314 orang mahasiswa, Fakultas Ekonomi Universitas Mahendradatta memilki 266 orang mahasiswa dan Fakultas Ekonomi Universitas Warmadewa memiliki 788 orang mahasiswa.

Mahasiswa Fakultas Ekonomi Universitas Warmadewa diberikan tugas untuk membuat proposal rencana berwirausaha yang termasuk didalam metode pengajaran mata kuliah kewiraausahan. Tujuan dari tugas ini agar para mahasiswa dapat memiliki ide kreatif dan rencana untuk berwirausaha. Mahasiswa Fakultas Ekonomi Universitas Warmadewa diharapkan menjadi lulusan yang mandiri dan 
dapat menciptakan lapangan pekerjaan sendiri, maka dari itu pihak fakultas mendukung kegiatan mahasiswa dalam kerjasama kewirausahaan. Melalui adanya kerjasama tersebut, HIPMI Kota Denpasar menunjuk Fakultas Ekonomi Unwar khususnya jurusan manajemen untuk mengikuti Jambore Kewirausahaan seASEAN di Bandung, Jawa Barat pada tanggal 22 sampai dengan 26 Mei 2016. Kegiatan ini bertujuan agar para lulusan S1 reguler Fakultas Ekonomi Unwar memiliki pengetahuan kewirausahaan sehingga menjadi wirausaha yang mampu menghadapi berbagai masalah ekonomi. Fakultas Ekonomi Unwar juga sering kali menggelar seminar kewirausahaan untuk mahasiswa, pegawai dan dosen. Narasumber seminar mulai dari kalangan nasional hingga internasional.

Penelitian ini merupakan replikasi dari penelitian yang dilakukan oleh Sarwoko (2011), sedikit dimodifikasi untuk variabel norma subyektif menjadi variabel pendidikan kewirausahaan dan tempat dilaksanakan penelitian ini diganti menjadi FE Universitas Warmadewa. Berdasarkan uraian diatas, maka fenomena tersebut menjadi menarik untuk diteliti khususnya dikaitkan dengan Fakultas Ekonomi Universitas Warmadewa yang mendukung mahasiswa untuk mengikuti kegiatan dan pendidikan mengenai kewirausahaan. Variabel dalam penelitian ini diharapkan dapat membantu mengetahui dan menjelaskan faktor-faktor yang dipertimbangkan dalam niat berwirausaha

Penelitian yang dilakukan Gerba (2012), menemukan bahwa siswa manajemen bisnis di Ethiopia yang mendapatkan pendidikan kewirausahaan lebih memiliki niat kewirausahaan dibandingkan mahasiswa teknik yang tidak mendapatkan pendidikan kewirausahaan. Sedangkan penelitian lain menyakini 
Putu Ayu Dian Darmayanti, Membangun Intensi Berwirausaha...

bahwa kewirausahaan tidak dapat diajarkan karena wirausaha lahir dengan bakat alaminya, yang dapat diartikan bahwa pendidikan kewirausahaan tidak mempengaruhi niat berwirausaha (Lupiyohadi, 2007). Berdasarkan beberapa kajian empiris sebelumnya, maka dapat disusun hipotesis sebagai berikut:

$\mathrm{H}_{1}$ : Pendidikan kewirausahaan secara positif dan signifikan memengaruhi intensi berwirausaha mahasiswa

Beberapa hasil penilitian menunjukan bahwa efikasi diri (self efficacy) berpengaruh positif terhadap intensi kewirausahaan, seperti penelitian Indarti \& Rosiani (2008) menyatakan bahwa efikasi diri terbukti berpengaruh positif terhadap intensi berwirausaha mahasiswa. Penelitian Vemmy (2012), mengatakan bahwa self efficacy berpengaruh positif dan signifikan terhadap intensi berwirausaha. Begitu pula penelitian oleh Sarwoko (2011) hasil penelitian ini menunjukkan bahwa hanya norma subjektif dan efikasi diri yang mampu mendukung intensi untuk berwirausaha mahasiswa, artinya niat wirausaha mahasiswa ditentukan oleh tingginya dukungan pada diri mahasiswa baik dukungan dari keluarga maupun dukungan dari orang yang dianggap berpengaruh. Pernyataan tersebut sama dengan pernyataan Habib \& Rahyuda (2015), yang menyatakan secara tidak langsung efikasi diri berpengaruh positif dan signifikan melalui keberanian mengambil risiko terhadap niat berwirausaha. Penelitian serupa dilakukan oleh Samydevan et al (2015), efikasi diri berhubungan positif terhadap niat berwirausaha. Sedangkan ada beberapa penelitian yang memiliki perbedaan, seperti penelitian Wijaya (2008) \& Segal et al (2005), menyatakan bahwa efikasi diri terbukti tidak mempengaruhi intensi 
berwirausaha. Berdasarkan beberapa kajian empiris sebelumnya, maka dapat disusun hipotesis sebagai berikut:

$\mathrm{H}_{2}$ : Efikasi diri secara positif dan signifikan memengaruhi intensi berwirausaha mahasiswa.

Menurut Tong et al (2011), menyatakan bahwa siswa akan memilih untuk menjadi pengusaha asalkan ada kebutuhan untuk berprestasi (need for achievement), latar belakang bisnis keluarga dan pengaruh subjektif. Selain itu menurut Oktarilis (2012), kebutuhan akan prestasi menunjukkan keinginan seseorang untuk membuat sesuatu atau bekerja dengan lebih baik, atau lebih cepat dibandingkan dengan prestasi orang lain atau prestasi masa lalunya. Kebutuhan akan prestasi secara signifikan berpengaruh positif terhadap keinginan menjadi wirausaha. Seseorang yang memiliki kebutuhan akan prestasi akan lebih mengejar pekerjaan wirausaha dari pada jenis pekerjaan lain. Seseorang yang memiliki kebutuhan akan prestasi yang tinggi akan lebih banyak berkontribusi dalam kegiatan wirausaha (Xue et al, 2011).

Hasil penelitian Vemmy (2012), menunjukan juga bahwa kebutuhan akan berprestasi secara signifikan berpengaruh positif terhadap intensi berwirausaha. Sejalan dengan penelitian Ferreira et al., (2012) menunjukkan bahwa Need for Achievement berpengaruh secara positif terhadap niat berwirausaha. Penelitian tersebut berbanding terbalik dengan penelitian menurut Ogunleye (2014) menyatakan bahwa kebutuhan akan prestasi bukan prediktor yang signifikan terhadap orientasi wirausaha. Begitu pula menurut Achadiyah (2013), dalam penelitiannya menunjukkan bahwa kebutuhan akan prestasi tidak signifikan 
Putu Ayu Dian Darmayanti, Membangun Intensi Berwirausaha...

mempengaruhi niat berwirausaha, secara statistik hal tersebut ditunjukkan dengan nilai signifikansi hasil penelitian yang lebih besar dari alpha $(0,05)$. Berdasarkan kajian empiris tersebut, maka dapat disusun hipotesis sebagai berikut:

$\mathrm{H}_{3}$ : Kebutuhan akan prestasi secara positif dan signifikan memengaruhi intensi berwirausaha mahasiswa.

\section{METODE PENELITIAN}

Penelitian ini berbentuk penelitian asosiatif, karena dalam penelitian ini membahas tentang pengaruh variabel bebas terhadap variabel terikat .Penelitian ini didesain untuk mencari pengaruh pendidikan kewirausahaan (X1), efikasi diri (X2) dan kebutuhan berprestasi (X3) terhadap intensi kewirausahaan di kalangan mahasiswa Fakultas Ekonomi Universitas Warmadewa. Subjek penelitian merupakan suatu anggota dari sampel, sebagaimana elemen merupakan satu anggota dari populasi (Sekaran 2006: 123). Dalam penelitian ini, subjek penelitian yang digunakan adalah Mahasiswa aktif S1 Reguler Fakultas Ekonomi Universitas Warmadewa. Alasan dipilihnya pada mahasiswa S1 Fakultas Ekonomi Universitas Warmadewa karena memiliki tujuan pendidikan yaitu menghasilkan lulusan ekonomi yang unggul, beretika, berorientasi lingkungan dan mandiri sehingga mampu menciptakan lapangan kerja sendiri dan memberikan mata kuliah yang dapat menciptakan jiwa berwirausaha di mata mahasiswa (FE Unwar, 2010) Objek penelitian merupakan variabel penelitian yang segala sesuatu berbentuk apa saja yang sudah ditetapkan oleh peneliti untuk dipelajari sehingga didapatnya informasi tentang hal tersebut dan akhirnya ditarik kesimpulannya 
(Sugiyono, 2014: 58). Objek penelitian ini yaitu mengenai perilaku yang difokuskan pada niat berwirausaha

Variabel independen atau bebas merupakan variabel yang mempengaruhi atau yang menjadi sebab perubahannya atau timbulnya variabel dependen atau terikat (Sugiyono, 2014). Variabel bebas dalam penelitian ini adalah pendidikan kewirausahaan $\left(\mathrm{X}_{1}\right)$, efikasi diri $\left(\mathrm{X}_{2}\right)$ dan kebutuhan akan prestasi $\left(\mathrm{X}_{3}\right)$. Variabel dependen atau terikat merupakan variabel yang dipengaruhi atau yang menjadi akibat karena adanya variabel bebas (Sugiyono, 2014).Variabel terikat dalam penelitian ini adalah intensi berwirausaha $(y)$.

Data primer pada penelitian ini adalah data yang didapatkan secara langsung mengenai kuesioner, yakni jawaban responden terhadap kuesioner yang disebarkan oleh penulis kepada mahasiswa S1 reguler Fakultas Ekonomi Universitas Warmadewa mengenai pengaruh pendidikan kewirausahaan, efikasi diri dan kebutuhan berprestasi terhadap intensi berwirausaha. Data sekunder diperoleh melalui studi pustaka dengan mencari teori - teori yang berkaitan dengan variabel yang diteliti, dan data mengenai jumlah mahasiswa angkatan 2015 Fakultas Ekonomi Universitas Warmadewa yang didapat dari Bagian Administrasi maupun Bagian Akademik di Universitas tersebut.

Populasi merupakan generalisasi wilayah atas objek atau subjek yang memiliki karakteristik dan kualitas tertentu yang ditetapkan peneliti untuk dipelajari dan ditarik kesimpulannya, (Sugiyono, 2014:115). Populasi dalam penelitian ini adalah seluruh mahasiswa aktif Fakultas Ekonomi Universitas Warmadewa S1 Reguler angkatan 2015 yang lulus mata kuliah kewirausahaan. 
Putu Ayu Dian Darmayanti, Membangun Intensi Berwirausaha...

Menurut Sugiyono (2014:81) sampel adalah bagian dari jumlah dan karakteristik yang dimiliki oleh populasi tersebut. Sampel dilakukan karena keterbatasan peneliti dalam melakukan penelitian baik dari segi dana, waktu, tenaga dan jumlah populasi yang sangat banyak. Oleh karena itu sampel yang diambil harus betulbetul representative (dapat mewakili). Menurut Sugiyono (2013:132) menyatakan bahwa untuk memperoleh hasil dari kuesioner, diperlukan jumlah sampel responden yang diambil untuk mengisi kuesioner dapat ditentukan paling sedikit 5-10 kali jumlah variabel yang diteliti. Karena jumlah indikator ini adalah berjumlah 17 indikator, maka jumlah sampel yang ideal dalam penelitian ini adalah berkisar antara 75 sampai 150 responden jadi jumlah sampel yang digunakan dalam penelitian ini adalah 100 responden.

Teknik sampling yang digunakan dalam penelitin ini adalah Non Probability Sampling karena tidak memberikan peluang yang sama pada anggota populasi. Teknik Non Probability Sampling yang digunakan dalam penelitian ini adalah Purposive Sampling, yaitu pengambilan anggota sampel dilakukan dengan pertimbangan tertentu, pertimbangan atau kriteria yang dimaksud adalah: Tercatat sebagai mahasiswa aktif program S1 angkatan 2015 Fakultas Ekonomi Universitas Warmadewa dan Telah lulus mata kuliah kewirausahaan

Penelitian ini menggunakan kuesioner sebagai salah satu alat pengumpul data, sehingga perlu dilakukan pengujian validitas dan realibilitas agar kuesioner tersebut layak digunakan sebagai alat pengumpul data. Sugiyono (2014:172) mengungkapkan bahwa instrumen yang valid adalah instrumen yang dapat digunakan untuk mengukur apa yang seharusnya diukur. Hasil penelitian akan 
menjadi valid jika menggunakan instrumen yang valid dalam pengumpulan data. Jadi, instrumen yang valid merupakan syarat mutlak untuk mendapatkan hasl penelitian yang valid. Suatu variabel dikatakan valid apabila $r$ alpha $>r$ tabel. Menurut Sugiyono (2014:178) suatu instrumen dikatakan valid apabila nilai korelasinya $(r) \geq 0,3$. Instrumen yang reliable adalah instrumen yang apabila digunakan beberapa kali untuk mengukur obyek yang sama, akan menghasilkan data yang sama (Sugiyono, 2014:172). Suatu variabel dikatakan reliabel apabila $\mathrm{r}$ alpha > r table. Menurut Sugiyono (2014:189) suatu instrumen dikatakan reliabel apabila nilai korelasinya (r) di atas 0,6 atau nilai Alpha Cronbach $\geq 0,6$.

Model analisis yang digunakan dalam penelitian ini adalah analisis regresi berganda dengan bantuan SPSS (Statistical Packagefor Social Science). Model analisis regresi berganda digunakan untuk mengetahui hubungan antara variabel dependen (terikat) dengan variabel independen (bebas) baik secara simultan maupun secara parsial. Model regresi berganda ditunjukkan pada persaman di bawah ini :

$$
\mathbf{Y}=\mathbf{a}+\mathbf{b}_{1} \mathbf{X}_{1}+\mathbf{b}_{2} \mathbf{X}_{2}+\mathbf{b}_{3} \mathbf{X}_{3}
$$

Dimana :

$\begin{array}{ll}\mathbf{Y} & =\text { Intensi berwirausaha } \\ \boldsymbol{X}_{\mathbf{1}} & =\text { Variabel pendidikan kewirausahaan } \\ \boldsymbol{X}_{\mathbf{2}} & =\text { Variabel efikasi diri } \\ \mathbf{X}_{\mathbf{3}} & =\text { Variabel kebutuhan akan prestasi } \\ \boldsymbol{\alpha} & =\text { Konstanta } \\ \boldsymbol{b}_{\mathbf{1}}, \boldsymbol{b}_{\mathbf{2}}, \boldsymbol{b}_{\mathbf{3}} & =\text { Koefisien masing-masing factor }\end{array}$

\section{PEMBAHASAN PENELITIAN}


Putu Ayu Dian Darmayanti, Membangun Intensi Berwirausaha...

Pengujian data dalam penelitian ini menggunakan teknik analisis regresi berganda. Tahapan melakukan teknik analisis regresi berganda. Perhitungan koefisien regresi berganda dilakukan dengan analisis regresi melalui software SPSS diperoleh hasil yang ditunjukan pada Tabel 1 berikut :

Tabel 1.

Hasil Uji Regresi Berganda

\begin{tabular}{|c|c|c|c|}
\hline $\begin{array}{c}\text { Hasil Analisis Regresi Linier } \\
\text { Berganda Variabel }\end{array}$ & $\begin{array}{l}\text { Koefisien } \\
\text { Regresi }\end{array}$ & Sig.t & $\begin{array}{l}\text { Konstanta }=\mathbf{0 , 0 0 0} \\
\text { R Square }=\mathbf{0 , 6 8 8} \\
\text { F sig }=\mathbf{0 , 0 0 0}\end{array}$ \\
\hline Pendidikan Kewirausahaan & 0,450 & 0,000 & \\
\hline Efikasi Diri & 0,280 & 0,001 & \\
\hline Kebutuhan akan Prestasi & 0,258 & 0,001 & \\
\hline
\end{tabular}

Nilai determinasi total sebesar 0,688 mempunyai arti bahwa sebesar $68,8 \%$ variasi intensi kewirausahaan dipengaruhi oleh variasi pendidikan kewirausahaan, efikasi diri, dan kebutuhan akan prestasi sedangkan sisanya sebesar 31,2\% dijelaskan oleh faktor lain yang tidak dimasukkan ke dalam model.

Uji normalitas bertujuan untuk mengetahui apakah residual dari model regresi yang dibuat berdistribusi normal atau tidak. Untuk menguji apakah data yang digunakan normal atau tidak dapat dilakukan dengan menggunakan uji Kolmogorov Sminarnov. Apabila koefisien hasil uji dua sisi lebih besar dari 0,05 maka data tersebut dikatakan berdistribusi normal.

\section{Tabel 2}

Uji Normalitas

\section{Hasil Uji Normalitas Unstandardized Residual}

$\mathrm{N} \quad 100$

Normal Parametersa,b Mean $\quad 0,0000000$

Std. Deviation $\quad 1,20926342$

Most Extreme Absolute $\quad 0,48$

Differences Positive $\quad 0,42$

Negative $\quad 0,48$

Kolmogrov-Smirnov Z $\quad 0,485$

Asymp. Sig. (2-tailed) $\quad 0,973$

Data Primer diolah 2017 
Berdasarkan Tabel 2 dapat dilihat bahwa nilai Kolmogorov Sminarnov (KS) sebesar 0,485, sedangkan nilai hasil uji dua sisi sebesar 0,973. Hasil tersebut mengindikasikan bahwa model persamaan regresi tersebut berdistribusi normal karena nilai hasil uji dua sisi 0,973 lebih besar dari nilai alpha 0,05.

Uji ini bertujuan untuk menguji apakah pada model regresi ditemukan adanya korelasi antar variabel bebas. Adanya multikolinearitas dapat dilihat dari nilai tolerance atau variance inflation factor (VIF). Jika nilai tolerance lebih dari $10 \%$ atau VIF Kurang dari 10, maka dikatakan tidak ada multikolinearitas.

Tabel 3.

Hasil Uji Multikolinearitas

\begin{tabular}{llll}
\hline No. & Variabel & Tolerance & VIF \\
\hline 1. & Pendidikan Kewirausahaan $\left(\mathrm{X}_{1}\right)$ & 0,665 & 1,504 \\
\hline 2. & Efikasi Diri $\left(\mathrm{X}_{2}\right)$ & 0,515 & 1,940 \\
\hline 3. & Kebutuhan akan Prestasi $\left(\mathrm{X}_{3}\right)$ & 0,581 & 1,721
\end{tabular}

Data Primer diolah 2017

Berdasarkan Tabel 3 dapat dilihat bahwa nilai tolerance dan VIF dari seluruh variabel menunjukkan bahwa nilai tolerance untuk setiap variabel lebih dari 10 persen dan nilai VIF lebih kecil dari 10 yang berarti model persamaan regresi bebas dari multikolinearitas.

Uji ini bertujuan untuk mengetahui apakah dalam model regresi terjadi ketidaksamaan varians dari residual satu pengamatan ke pengamatan lain yang dilakukan dengan uji Glejser. Jika tidak ada satu pun variabel bebas yang berpengaruh signifikan terhadap nilai absolute residual atau nilai signifikansinya di atas 0,05 maka tidak mengandung gejala heteroskedastisitas.

Tabel 4.

Hasil Uji Heterokedastisitas

\begin{tabular}{llll}
\hline No. & \multicolumn{1}{c}{ Variabel } & \multicolumn{1}{c}{ Thitung } & Sig. \\
\hline 1. & Pendidikan Kewirausahaan $\left(\mathrm{X}_{1}\right)$ & 1,071 & 0,287 \\
\hline 2. & Efikasi Diri $\left(\mathrm{X}_{2}\right)$ & $-0,943$ & 0,348 \\
\hline 3. & Kebutuhan akan Prestasi $\left(\mathrm{X}_{3}\right)$ & $-1,659$ & 0,100 \\
\hline
\end{tabular}


Putu Ayu Dian Darmayanti, Membangun Intensi Berwirausaha...

Data Primer diolah 2017

Pada Tabel 4 dapat dilihat bahwa nilai Sig. dari variabel Pendidikan Kewirausahaan, Efikasi Diri dan Kebutuhan akan Prestasi, masing-masing sebesar 0,$287 ; 0,348$ dan 0,100 Nilai tersebut lebih dari 0,05 yang berarti tidak terdapat pengaruh antara variabel bebas terhadap absolute residual. Dengan demikian, model yang dibuat tidak mengandung gejala heteroskedastisitas.

Uji signifikansi atau uji ketepatan model atau yang lebih populer disebut sebagai uji F (ada juga yang menyebutnya sebagai uji simultan model) merupakan tahapan awal mengidentifikasi model regresi yang diestimasi layak atau tidak. Layak (andal) disini maksudnya adalah model yang diestimasi layak digunakan untuk menjelaskan pengaruh variabel-variabel bebas terhadap variabel terikat. Nama uji ini disebut sebagai uji F, karena mengikuti mengikuti distribusi F yang kriteria pengujiannya seperti One Way Anova. Sig. Tabel ANOVA menunjukkan besarnya angka probabilitas atau signifikansi pada perhitungan ANOVA. Nilai yang tertera digunakan untuk uji kelayakan model analisis (dimana sejumlah variabel x mempengaruhi variabel y) dengan ketentuan angka probabilitas yang baik untuk digunakan sebagai model regresi harus $<0,05$. Nilai ini bisa dilihat pada kolom Sig. Jika signifikansi < 0,05, maka model analisis dianggap layak. Jika nilai signifikansi > 0,05, maka model analisis dianggap tidak layak.

Tabel 5.

Hasil Uji F ANOVA ${ }^{b}$

\begin{tabular}{llrrrrr}
\hline Model & & Sum of Squares & Df & Mean Square & F & \multicolumn{1}{c}{ Sig. } \\
\hline \multirow{2}{*}{1} & Regression & 318.871 & 3 & 106.290 & 70.483 & $.000^{\mathrm{a}}$ \\
\cline { 2 - 7 } & Residual & 144.769 & 96 & 1.508 & & \\
\cline { 2 - 7 } & Total & 463.640 & 99 & & & \\
\hline
\end{tabular}

Data Primer diolah 2017 
Pada Tabel 4.18 hasil uji anova (UJI F) di atas, diperoleh nilai antar kelompok pembanding $=3$, nilai dalam kelompok penyebut $=99$, pada probabilitas $=0,05$ maka nilai $\mathrm{F}$ tabelnya adalah $\mathrm{F} 0,05(3,99)=2,70$. Sedang $\mathrm{F}$ hitung $=70,483$. Nilai Fhitung $>$ Ftabel, 70,483 $>2,70$, dengan nilai signifikansi 0,000 < 0, 05. Maka H0 ditolak pada taraf nyata 0,05 (H1 diterima). Kesimpulannya, pada kelompok yang diuji memiliki perbedaan yang nyata (signifikan) yang berarti bahwa pendidikan kewirausahaan, efikasi diri dan kebutuhan akan prestasi secara simultan berpengaruh signifikan terhadap intensi kewirausahaan. Kriteria pengujian hipotesis untuk menjelaskan interpretasi pengaruh antar masing-masing variabel sebagai berikut. Jika nilai signifikansi < 0.05 maka $\mathrm{H}_{0}$ ditolak dan $\mathrm{H}_{1}$ diterima. Jika nilai signifikansi > 0.05 maka $\mathrm{H}_{0}$ diterima dan $\mathrm{H}_{1}$ ditolak. Berdasarkan hasil analisis pengaruh Pendidikan Kewirausahaan Terhadap Intensi Kewirausahaan diperoleh nilai signifikansi sebesar 0,000 dengan nilai koefisien regresi 0,450. Nilai Signifikansi $0,000<$ 0,05 mengindikasikan bahwa $\mathrm{H}_{0}$ ditolak dan $\mathrm{H}_{1}$ diterima. Hasil ini mempunyai arti bahwa Pendidikan Kewirausahaan berpengaruh positif dan signifikan Terhadap Intensi Berwirausaha. Berdasarkan hasil analisis pengaruh Efikasi Diri Terhadap Intensi Kewirausahaan diperoleh nilai signifikansi sebesar 0,001 dengan nilai koefisien regresi 0,280 . Nilai Signifikansi $0,001<0,05$ mengindikasikan bahwa $\mathrm{H}_{0}$ ditolak dan $\mathrm{H}_{1}$ diterima. Hasil ini mempunyai arti bahwa Efikasi Diri berpengaruh positif dan signifikan terhadap Intensi Kewirausahaan. Berdasarkan hasil analisis pengaruh Kebutuhan Akan Prestasi terhadap Intensi Kewirausahaan diperoleh nilai signifikansi sebesar 0,001 dengan nilai koefisien regresi 0,258. 
Putu Ayu Dian Darmayanti, Membangun Intensi Berwirausaha...

Nilai Signifikansi $0,001<0,05$ mengindikasikan bahwa $\mathrm{H}_{0}$ ditolak dan $\mathrm{H}_{1}$ diterima. Hasil ini mempunyai arti bahwa Kebutuhan Akan Prestasi berpengaruh positif dan signifikan terhadap Intensi Kewirausahaan.

\section{PEMBAHASAN HASIL PENELITIAN}

Berdasarkan hasil analisis pengaruh pendidikan kewirausahaan terhadap intensi berwirausaha diperoleh nilai Signifikansi sebesar 0,000 dengan nilai koefisien beta 0,450 . Hal ini mengindikasikan bahwa pendidikan kewirausahaan memiliki pengaruh positif terhadap intensi berwirausaha. Dimana semakin jelas tujuan dari pengajaran pendidikan mahasiswa terhadap kewirausahaan maka semakin tinggi intensi (niat) mahasiswa dalam berwirausaha. Dimana semakin banyak materi kewirausahaan yang diberikan kepada mahasiswa, maka semakin tinggi intensi (niat) mahasiswa dalam berwirausaha. Dimana semakin banyak ketrampilan kewirausahaan yang diberikan kepada mahasiswa, maka semakin tinggi intensi (niat) mahasiswa dalam berwirausaha. Dimana semakin efektif metode pengajaran kewirausahaan yang diberikan kepada mahasiswa, maka semakin tinggi intensi (niat) mahasiswa dalam berwirausaha. Hasil penelitian ini mendukung temuan dari Indarti dan Rostiani (2008), Suharti dan Sirine (2011), dan $\mathrm{Wu}$ dan $\mathrm{Wu} 2008$ yang menemukan hasil bahwa pendidikan kewirausahaan memiliki pengaruh postif terhadap intensi berwirausaha

Berdasarkan hasil analisis pengaruh efikasi diri terhadap intensi berwirausaha diperoleh nilai Signifikansi sebesar 0,001 dengan nilai koefisien beta 0,280 . Ini mengindikasikan bahwa efikasi diri memiliki pengaruh positif terhadap intensi berwirausaha. Hal ini mengindikasikan bahwa efikasi diri 
memiliki pengaruh positif terhadap intensi berwirausaha. Dimana semakin besar kepercayaan diri mahasiswa terhadap kewirausahaan maka semakin tinggi intensi (niat) mahasiswa dalam berwirausaha. Dimana semakin besar jiwa kepemimpinan mahasiswa terhadap kewirausahaan maka semakin tinggi intensi (niat) mahasiswa dalam berwirausaha. Dimana semakin besar kematangan mental mahasiswa terhadap kewirausahaan maka semakin tinggi intensi (niat) mahasiswa dalam berwirausaha. Dimana semakin besar kemampuan mengelola mahasiswa terhadap kewirausahaan maka semakin tinggi intensi (niat) mahasiswa dalam berwirausaha. Penelitian ini mendukung temuan dari Indarti \& Rosiani (2008), Samydevan et al (2015), dan Vemmy (2012) yang menjelaskan efikasi diri memiliki pengaruh yang positif terhadap intensi berwirausaha.

Berdasarkan hasil analisis pengaruh kebutuhan akan prestasi terhadap intensi berwirausaha diperoleh nilai signifikansi sebesar 0,001 dengan nilai koefisien beta 0,258 . Hal ini mengindikasikan bahwa kebutuhan akan prestasi memiliki pengaruh positif terhadap intensi berwirausaha. Dimana semakin banyak tantangan pekerjaan mahasiswa terhadap kewirausahaan, maka semakin tinggi intensi (niat) mahasiswa dalam berwirausaha. Dimana semakin baik hasil yang dicapai mahasiswa dari sebelumnya, maka semakin tinggi intensi (niat) mahasiswa dalam berwirausaha. Dimana semakin besar tanggung jawab mahasiswa terhadap kewirausahaan maka semakin tinggi intensi (niat) mahasiswa dalam berwirausaha. Dimana semakin baik hasil yang dicapai mahasiswa dari orang lain, maka semakin tinggi intensi (niat) mahasiswa dalam berwirausaha. Hal ini menunjukan adanya keinginan mahasiswa untuk memulai usaha dan 
Putu Ayu Dian Darmayanti, Membangun Intensi Berwirausaha...

mengembangkan ide-ide baru dalam berwirausaha. Penelitian ini mendukung temuan dari Tong et al (2011), Oktarilis (2012), dan Xue et al, (2011) yang menjelaskan bahwa efikasi diri memiliki pengaruh positif terhadap intensi berwirausaha.

Berdasarkan hasil penelitian yang diperoleh, pernyataan responden tentang "Saya merasa materi yang disajikan dalam mata kuliah kewirausahaan telah menambah keterampilan saya dalam bidang kewirausahaan", memiliki nilai outer loadings tertinggi dibandingkan pernyataan lain, maka dapat dijelaskan bahwa pernyataan tersebut dapat merefleksikan pendidikan kewirausahaan responden. Lalu pernyataan responden tentang "Saya yakin akan kemampuan saya untuk menjadi wirausaha dan memulai suatu usaha baru", memiliki nilai outer loadings tertinggi dibandingkan pernyataan lain, maka dapat dijelaskan bahwa pernyataan tersebut dapat merefleksikan efikasi diri responden. Kemudian pernyataan responden tentang "Saya selalu ingin membuat segala sesuatunya lebih baik daripada orang lain", memiliki nilai outer loadings tertinggi dibandingkan pernyataan lain, maka dapat dijelaskan bahwa pernyataan tersebut dapat merefleksikan kebutuhan akan prestasi responden.. Selanjutnya pernyataan responden tentang "Saya berharap untuk dapat menciptakan bisnis baru dimasa mendatang" maka dapat dijelaskan bahwa pernyataan tersebut dapat merefleksikan intensi berwirausaha responden.

Berdasarkan pembahasan tersebut maka terdapat beberapa implikasi penelitian yang dihasilkan. Pertama, terbukti bahwa responden memiliki ketrampilan dan pengetahuan dalam hal berwirausaha setelah mengikuti materi 
pendidikan kewirausahaan. Setelah/saat responden mengikuti mata kuliah kewirausahaan pola pikir responden akan terbentuk menjadi seorang entrepreneur maka berarti metode pengajaran yang diterapkan dalam kelas kewirausahaan adalah metode yang efektif.

Implikasi yang kedua yaitu, berdasarkan hasil penelitian yang diperoleh bahwa variabel efikasi diri secara signifikan berpengaruh positif terhadap intensi berwirausaha, maka dapat diartikan bahwa efikasi diri akan mempengaruhi intensi berwirausaha pada mahasiswa Fakultas Ekonomi Universitas Warmadewa. Semakin tinggi kepercayaan diri atau keyakinan diri maka akan meningkat pula intensi (niat) berwirausaha. Hal tersebut menunjukkan bahwa mahasiswa dengan kepercayaan diri dan keyakinan diri akan membawa pengaruh yang cukup besar terhadap intensi berwirausaha mahasiswa, sehingga dapat dikatakan sebagai salah satu faktor penentu dalam intensi berwirausaha.

Implikasi yang ketiga, berdasarkan hasil penelitian yang diperoleh bahwa variabel kebutuhan akan prestasi secara signifikan berpengaruh positif terhadap intensi berwirausaha, maka dapat diartikan bahwa kebutuhan akan prestasi akan mempengaruhi intensi berwirausaha pada mahasiswa Fakultas Ekonomi Universitas Warmadewa. Semakin tinggi kebutuhan dan keinginan mendapatkan prestasi maka akan meningkat pula intensi (niat) berwirausaha. Hal tersebut menunjukkan bahwa mahasiswa dengan kebutuhan atau keinginan mendapatkan prestasi membawa pengaruh yang cukup besar terhadap intensi berwirausaha mahasiswa, sehingga dapat dikatakan sebagai salah satu faktor penentu dalam intensi berwirausaha. 
Putu Ayu Dian Darmayanti, Membangun Intensi Berwirausaha...

Implikasi yang keempat yaitu di dalam intensi berwirausaha didapatkan hasil bahwa indikator "Saya berharap untuk dapat menciptakan bisnis baru dimasa mendatang" menjadi indikator yang memiliki nilai rata-rata tertinggi dibandingkan dengan indikator lainnya. Total rata-rata dari seluruh pernyataan tentang mendapatkan keterangan sangat tinggi, hal ini berarti responden mempunyai harapan atau niat untuk memulai suatu usaha baru di masa depan. Hal ini menjadi modal yang sangat penting bagi FE Universitas Warmadewa untuk terus bahkan menambahkan lagi materi dan kegiatan yang membuat mahasiswa mempunyai intensi (niat) berwirausaha di masa depan, sehingga dapat menghasilkan lulusan yang berkualitas dalam bidang kewirausahaan.

Berkaitan dengan deskripsi responden yang mayoritas jurusan manajemen, serta berjenis kelamin perempuan, serta pekerjaan orang tuanya adalah pegawai swasta maka mayoritas responden yang memiliki intensi berwirausaha dapat dikatakan mahasiswa perempuan jurusan manajemen yang mempunyai latar belakang pekerjaan orang tuanya adalah pegawai swasta yang sudah memiliki ide berwirausaha setelah lulus kuliah. Sehingga pihak fakultas dapat memaksimalkan kegiatan atau pendidikan kewirausahaan yang menjadi mata kuliah wajib mahasiswa.

\section{SIMPULAN DAN SARAN}

Berdasarkan hasil pembahasan penelitian yang telah dilakukan, maka dapat disimpulkan bahwa pendidikan kewirausahaan secara signifikan berpengaruh positif terhadap intensi berwirausaha. Pendidikan kewirausahaan mempengaruhi mahasiswa FE S1 Unwar untuk memiliki pola pikir berwirausaha, 
mendapatkan pengetahuan kewirausahaan, mendapatkan ketrampilan kewirausahaan, dan mendapatkan metode pengajaran kewirausahaan yang efektif. Efikasi diri secara signifikan berpengaruh positif terhadap intensi berwirausaha. Efikasi diri membuat mahasiswa FE S1 Unwar memiliki rasa kepercayaan diri untuk dapat memimpin diri sendiri maupun orang lain, memiliki rasa kepercayaan diri dalam keberhasilan usaha, kematangan mental dan kemampuan mengelola usaha agar tetap bertumbuh. Kebutuhan berprestasi secara signifikan berpengaruh positif terhadap intensi berwirausaha. Ini menjelaskan bahwa mahasiswa FE S1 Unwar menyukai pekerjaan yang menantang, pencapaian untuk hasil yang lebih baik dari sebelumnya, memiliki tanggung jawab yang tinggi terhadap pekerjaannya dan berkeinginan keras untuk selalu mendapatkan hasil yang lebih baik dari orang lain. Dalam mengembangkan jenis pendidikan kewirausahaan Fakultas Ekonomi Universitas Warmadewa dapat mewujudkan dengan pengembangan alternatif lain diluar matakuliah kewirausahaan seperti lomba berwirausaha dan pelatihan-pelatihan kewirausahaan sehingga akan semakin meningkatkan niat berwirausaha mahasiswa. Dalam pelaksanaan pendidikan kewirausahaan perlunya perhatian dari pemerintah dan lembaga pendidikan mengenai bagaimana metode pengajaran, kompetensi dosen dan lamanya waktu belajar sehingga dapat menambahkan minat berwirausaha pada mahasiswa. Tingginya kebutuhan akan prestasi, dan efikasi diri dapat menjadi modal penting bagi mahasiswa Fakultas Ekonomi Universitas Warmadewa dalam meningkatkan jiwa kewirausahaan. Pihak Fakultas Ekonomi lebih menekankan pada mata kuliah 
kewirausahaan maupun mata kuliah pendukung yang lain sehingga nantinya akan menghasilkan lulusan yang mempunyai jiwa wirausaha.

Berdasarkan hasil penelitian, masih terdapat beberapa keterbatasan pada penelitian ini. Keterbatsan-keterbatasan tersebut diharapkan dapat diperbaiki apabila penelitian sejenis dengan objek penelitian yang serupa akan dilakukan. Beberapa saran yang dapat diberikan kepada penelitian selanjutnya adalah mempertimbangkan untuk meneliti faktor-faktor lain diluar pendidikan kewirausahaan, efikasi diri dan kebutuhan akan prestasi untuk mengetahui niat berwirausaha, karena masih banyak faktor-faktor lain yang dapat mempengaruhi intensi berwirausaha seperti lingkungan orang tua, lingkungan social, lingkungan akademik dan lain-lain. Memperluas cakupan wilayah penelitian bukan hanya dilingkungan Fakultas Ekonomi saja misalnya dengan mengambil lokasi diseluruh Fakultas di Universitas Warmadewa maupun Universitas lain. Menambah jumlah responden dan memperluas sampel penelitian bukan hanya mahasiswa program S1 saja, namun bisa juga mahasiswa program lainnya. Mempersiapkan waktu, materi kajian ilmiah, perencanaan dan anggaran biaya penelitian yang lebih matang untuk dapat mendukung berjalannya penelitian yang lebih luas cangkupannya. Beberapa kelemahan dari penelitian ini adalah masih kurangnya faktor-faktor tersebut dalam memberikan hasil penelitian yang lebih handal.

\section{REFERENSI}

Achadiyah, B.N. dan D.T. Irafani. 2013. Perbandingan Intensi Kewirausahaan Mahasiswa Fakultas Ekonomi Universitas Negeri Malang: Jurusan Akuntansi, Manajemen dan Ekonomi Pembangunan. Jurnal Nominal, 2 (2), h: 162-180. 
Ajzen, Icek. 1991. The Theory of Planned Behavior, Organizational Behavior And Human Decision Processes. Organizational Behavior And Human Decision Processes, 50, pp: 179-211.

Augusty, Ferdinand. 2006. Metode Penelitian Manajemen: Pedoman Penelitian untuk skripsi, Tesis dan Disertai Ilmu Manajemen. Semarang: Universitas Diponegoro.

Alberti F, Sciasciadan Poli. 2004. Entrepreneurship Education: Notes on an Ongoing Debate. Disampaikan pada Proceedings of the 14th Annual International Entrepreneurship Conference, University of Nopoli, Federico II, Italy, 4-7 Juli 2004.

Alex Sobur. 2003. Psikologi umum. Bandung: Pustaka Setia.

Alwisol. 2011. Psikologi Kepribadian Edisi Revisi. Malang : UMM Press.

Bandura, A. 1997. Self efficacy: the Exercise of control. USA: W.H. Freemen dan Company. page 37

Basu, A., and Meghna Virick, 2007. Assesing Entrepreneurial Intention Among Students: A Comparative Study. Peer-Reviewed Papers: 71-86.

........Biro Pusat Statistik (BPS) Kota Denpasar. 2016. Bps.denpasar.go.id. Diakses pada 06/06/2017, 21:52 WITA.

........Biro Pusat Statistik (BPS) Nasional 2016. Bps.go.id. Diakses pada 06/06/2017, 20:55 WITA

Baumol, W. J., Litan, R. E., \& Schramm, C. J. 2007.Sustaining entrepreneurial capitalism. Capitalism and Society, 2(2) Article 1. Available at: http://www.bepress.com/cas/vol2/iss2/art1.

Choo, S., dan M. Wong, 2006. "Entrepreneurial intention: triggers and barriers to new venture creations in Singapore". Singapore Management Review 28 (2): 47-64.

Fatoki, Olawale Olufuns. 2010. Graduate Entrepreneurial Intention in South Africa: Motivations and Obstacles, Internasional Journal of Business and Management 5 (9), pp: 87-98.

Fayolle, A., Gailly B. \&Lassas-Clerc, N. 2006. Assessing the impact of entrepreneurship education programmes: A new methodology. Journal of European Industrial Training, 30(9): 701-720. 
Ferreira Joa ̃o J, M. L. Raposo, R.G. Rodrigues, A. Dinis and A. D. Pac so. 2012. A model of entrepreneurial intention An application of the psychological and behavioral approaches. Journal of Small Business and Enterprise Development, 19 (3), pp: 424-440.

Gerba, Dugassa Tessema. 2012. Impact of entrepreneurship education on entrepreneurial intentions of business and engineering students in Ethiopia. Journal of Economic and Management Studies, 3(2): 258-277.

Ghozali, Imam. 2013. Aplikasi Analisis Multivariate dengan Program SPSS. Semarang: Badan Penerbit Universitas Dipenogoro.

Habib, M.F dan Rahyuda, I. K. 2015. Pengaruh efikasi diri, kebutuhan akan prestasi dan keberanian mengambil risiko terhadap niat berwirausaha mahasiswa. E-jurnal Manajemen Unud, 4 (9), pp: 2618-2646.

Hamilton, R.T., \& Harper, D.A., 1994. The Entrepreneur in theory and Practice.Journal of Economic Studies, 21, 3-18

Hattab, Hala W. 2014. Impact of Entrepreneurship Education on Entrepreneurial Intention of University Students in Egypt, The Journal of Entrepreneurship 23 (1), pp: 1-18

Hermina, U. N, Syarifah, N dan Desvira, Z. 2011. Pengaruh mata kuliah kewirausahaan terhadap minat mahasiswa menjadi wirausaha pada program studi administrasi bisnis Politeknik Negeri Pontianak. Jurnal Eksos, 7(2), pp:130-141.

Hidayah, Tamriatin. 2011. Analisis Faktor-Faktor yang Memengaruhi Minat/Intensi Kewirausahaan Mahasiswa STIE Mandala Jember.

.http://ilmupengetahuanumum.com. 2016. 10 Negara dengan Jumlah Penduduk Populasi Terbanyak di Dunia. Diakses pada 14/09/2016, 20:17 WITA.

https://koinworks.com. 2017. Jumlah Pengusaha di Indonesia Meningkat. Diakses pada 07 Juni 2017, 12.30 WITA.

.http://www.kopagi.com. 2013. Gerakan Kewirausahaan Nasional. Diakses pada 20 Pebruari 2017, 11.40 WITA.

.http://www.warmadewa.ac.id/index.php/fakultas/4/Fakultas-Ekonomi. 2010. Profil Fakultas Ekonomi. Diakses pada 04/06/2017, 11:30 WITA.

Indarti, N. \& Rostiani, R. 2008. Intensi kewirausahaan mahasiswa: Studi perbandingan antara Indonesia, Jepang dan Norwegia. Jurnal Ekonomika 
dan Bisnis Indonesia, 23(4), 1-26.

Kennedy, J. and J. Drennan. 2001. A review of the impact of education and priorexperiance on new venture performance. The International Journal of Entrepreneurship and Innovation. 3(3). $153-69$.

Leon, J.A., Descals, F.J., and Dominguez, J.F. 2007. The Psychosocial Profile Of The University Entrepreneur. Journal of Psychology in Spain, 11(1), pp: 72-84.

Lupiyohadi, R. (2007). Entrepreneurship: From Mindset to Strategy. Jakarta: LP FE UI.

McClelland, David C. (1961). The Achieving Society. Princeton, New Jersey: D.VanNostrand Company, Inc.

Mujiati. 2003. Perkembangan Psikologi. Yogyakarta: Gadjah Mada University Press.

Nursito, Sarwono dan Arif Julianto Sri Nugroho. 2013. Analisis Pengaruh Interaksi Pengetahuan Kewirausahaan dan Efikasi Diri terhadap Intensi Kewirausahaan, Kiat Bisnis 5 (2), pp: 148-158

Ogunleye, J.A. and Osagu, J. C. 2014. Self-Efficacy, Tolerance for Ambiguity and Kebutuhan akan prestasias Predictors of Entrepreneurial Orientation among Entrepreneurs in Ekiti State, Nigeria. European Journal of Business and Management, 6 (17), pp: 240-250.

Oktarilis, Shabrina Nur. 2012. Pengaruh Faktor-faktor yang dapat Memotivasi Mahasiswa Berkeinginan Wirausaha. http://publication.gunadarma.ac.id/bitstream/123456789/5318/1/Jurnal\%2 0Entrepreneurship.pdf. Diunduh tanggal 3 November 2016.

Rustiyaningsih, Sri. 2013. Faktor-faktor yang Mempengaruhi Intensi Kewirausahaan, Widya Warta 2 (2), pp: 255-267.

Robert, Michael., Shepherd. (2008). Entrepreneurship Edition 7.NewYork: McGraw Hill Copmpany

Samydevan, Vijeyan. Shishi Kumar Piaralal, Abd Kadir Othman, dan Zahir Osman. 2015. Impact of Phychological Traits, Enterpreneurial Education and Culture in Determining Entrepreneurial Intention among PreUniversity Students in Malaysia. American Journal of Economics, Vol. 5(2) pp: 163-167.

Sarwoko, Endi. 2011. Kajian Empiris Entrepreneur Intention Mahasiswa .Journal 
Putu Ayu Dian Darmayanti, Membangun Intensi Berwirausaha...

Ekonomi dan Bisnis Th 16 No. 2

Segal, G., \& Borgia, D., Schoenfeld, J., 2005. The Motivation to Become an Entreprenur. International Journal of Entrepreneurial Behavior \& Research, 11, 42-57

Sekaran, Uma. 2006. Medote Penelitian Untuk Bisnis. Jakarta: Salemba Empat

Shane, S., Locke, E. and Collins, C. (2003)."Entrepreneurial motivation", Human Resource Management Review, 13, pp. 257-279.

Silvia. 2013. Pengaruh Entrepreneurial Traits dan Entrepreneurial Skills Terhadap Intensi Kewirausahaan: Studi Empiris Dapak Pendidikan Kewirausahaan pada Mahasiswa Universitas Kristen Petra Surabaya. Agora, 1(1), pp: 1-7.

Sinulingga, Albadi. 2012. Pengaruh Olahraga Kompetitif Terhadap Motif Berprestasi :Studi Komparatif antara Siswa Atlet dan Siswa Non-Atlet. S3 thesis, Universitas Pendidikan Indonesia. Hal 1-36.

Sugiyono. 2014. Metode Penelitian Bisnis (PendekatanKuantitatif, Kualitatif, dan $R \& D)$. Bandung: Alfabeta.

Suharti, Lieli dan ti Sirine. 2011. Faktor-faktor yang Berpengaruh terhadap Niat Kewirausahaan (Entrepreneurial Intention), Jurnal Manajemen dan Kewirausahaan 13 (2), pp: 124-134.

Suparta, Nyoman. dan Wayan Ramantha. 2010. Manajemen Bisnis Kecil dan Kewirausahaan. Edisi pertama. Denpasar: Pustaka Nayottama.

Suryana. 2007. Kewirausahaan. Jakarta: Salemba Empat.

Tong, Xue Fa, David Yoon Kin Tong dan Liang Chen Loy. 2011. Factors Influecing Entrepreneurial Intention Among University Students, International Journal of Social and Humanty Studies 3 (1), pp: 487-496

Utama, Made Suyana. 2010. Aplikasi Analisis Kuantitatif. Denpasar: Sastra Utama

Vemmy S, Caecilia 2012. Faktor-faktor yang Mempengaruhi Intensi Berwirausaha Siswa SMK. Jurnal Pendidikan, Jurnal Pendidikan Vokasi 2 (1), pp: 117-126.

Wardoyo. 2012. Pengaruh Pendidikan Dan Karakteristik Kewirausahaan Terhadap Intensi Berwirausaha Mahasiswa Pada Perguruan Tinggi Swasta Di Jakarta. Jurnal Bisnis. Vol 2. 
Winardi, J. 2003. Entrepreneur dan Entrepreneurship. Jakarta: Prenada Media.

Wu, S. Wu, L. 2008. The Impact of Higher Education on Entrepreneurial Intentions of University Students in China. Journal of Small Business and Enterprise Development,15(4), pp:752-774.

Wijaya, Tony. 2008. Kajian Model Empiris Perilaku Berwirausaha UKM DIY dan Jawa Tengah, Jurnal Manajemen dan Kewirausahaan, 10(2). pp: 93104

Wijaya, T. 2008. Studi Meta-Analisis Hubungan Efikasi Diri dan Sikap Toleransi Risiko Dengan Intensi Berwirausaha. Program Doktor Psikologi UGM. 